\title{
The Chronicle of Research and Scholarly Events in Legal and Constitutional History at the Faculty of Law and Administration of the Jagiellonian University in 2019
}

Key words: scholarly research, Legal and Constitutional History, Faculty of Law and Administration, Jagiellonian University

Słowa kluczowe: badania naukowe, historia państwa i prawa, Wydział Prawa i Administracji, Uniwersytet Jagielloński

The year 2019 was important for the Jagiellonian University: it not only became a formal member and co-founder of the University Alliance "UNA Europa", established on April $1^{\text {st }}, 2019$, but also was distinguished as one of the Research universities in the Polish IDUB ("Excellence Initiative - Research Universities") Program. Therefore, the Chairs of the Faculty of Law and Administration of the Jagiellonian University, which are concerned with legal and constitutional history, re-organised their activities in order to take part efficiently in both initiatives related to the above, focusing their efforts on the topic of Legal Heritage and the continuation of the most strategic projects already running, including the "Cracow Studies on Constitutional and Legal History" and the IURA database. Apart from those activities, normal scholarly and didactic work was carried on, and two conferences were organized jointly by several units of the Faculty.

\section{Joint Initiatives Involving Several Units}

The above mentioned conferences were organized jointly by the Chair of Polish Legal History, the Chair of General Legal History, the Chair of the History of Administration and Administrative Ideas, the Department of Ecclesiastical Law and Law on Religious Denominations, and the Editorial Board of the journal "Cracow Studies of Constitutional and Legal History" in September 2019. 
The first conference was the meeting held on September $19^{\text {th }} 2019$ under the title "Sources connect us", which was devoted to discussion of methods for the use of sources in the work of a legal historian, and of critical editions of those sources. It was dedicated to Professor Stanisław Grodziski, an outstanding editor of legal historical sources, who in 2019 reached the age of 90 years. During the initial, jubilee part of the conference, Professor Grodziski's achievements were recalled and acknowledged by officials of the University and the Faculty, Professor Wacław Uruszczak presented his laudation of the Jubilee, and Professor Grodziski himself gave a speech. After these events, 15 papers concerning methods and circumstances of edition of legal historical sources were presented and discussed. ${ }^{1}$

The second, international conference, titled "Unions of States in the Past. Theory and Practice" was held the on September $20^{\text {th }}$ and $21^{\text {st }}$. The topic of the conference corresponded with the $550^{\text {th }}$ anniversary of the Union of Lublin (1569), which led to the creation of the Polish-Lithuanian Commonwealth, a very specific example of a political union in European history. The proceedings consisted of two parts: a scholarly conference and a student panel. During the first part of the meeting, held on September $20^{\text {th }}$, 2019, eleven papers were presented by scholars from six countries (Austria, Croatia, Czechia, Hungary, Poland, and Ukraine). Between the sessions of the proceedings, a working meeting of the Advisory Board of the "Cracow Studies of Constitutional and Legal History" took place. In the subsequent student panel on September $21^{\text {st }}$, students from the University of Szeged along with four students from Jagiellonian University presented and discussed six papers. ${ }^{2}$

\section{Chair of Polish Legal History and Department of Ecclesiastical and Denominational Law}

In 2019 Prof. Stanisław Grodziski, emeritus of the Chair, published the $2^{\text {nd }}$, extended edition of his book Okruchy z glębi szuflady ["Crumbs from the depth of the drawer"], Kraków 2019 ( $1^{\text {st }}$ ed. 2015), containing varia concerning numerous topics. Another emeritus of the Chair, Prof. Wacław Uruszczak, was engaged in various undertakings related to the $450^{\text {th }}$ anniversary of the Union of Lublin (1569). Other professors and postgraduates of the Chair and the Department continued their scholarly activities in 2019, some of them also presenting results of their research on conferences inland and abroad. I.a. Dr. Hab. Maciej Mikuła spoke on testament in „Polish Municipal Law” in the $14^{\text {th }}-16^{\text {th }}$ centuries at a conference devoted to testaments of burghers (Cracow, $25^{\text {th }}$ June 2019), and on a digital corpus of sources of Polish medieval law during the „e-fontes” workshop (Cracow, 13 ${ }^{\text {th }}$ December 2019). At the 25th Annual Forum of Young Legal Historians in Brussels, June $5^{\text {th }}-8^{\text {th }}$, Jakub Pokoj spoke about "Identity, Citizenship and

${ }^{1}$ Cf. the report by D. Szczepaniak and the texts of Professor Uruszczak's laudation and Professor Grodziski's speech in the $1^{\text {st }}$ issue of this volume of „Cracow Studies...”.

${ }^{2}$ Further details may be found in two reports from the two parts of the conference, published in the $1^{\text {st }}$ issue of this volume of „Cracow Studies...”. 
Legal History" with his paper titled Citizenship during a transition period: The regulation of Polish citizenship in the first years of the Second Polish Republic (1918-1926).

It has been a long tradition in Cracow - reaching back to the times of Prof. Bolesław Ulanowski (1860-1919), and revived in 2002 by Prof. Wacław Uruszczak - that the study of Polish Legal History was strongly intertwined with research on Ecclesiastical and Denominational Law. It was in the year 2019, however, that especially numerous achievements worth mentioning in this section were compiled by the scholars of that subdiscipline.

Firstly, Dr. Marek Strzała published his monograph: Oświadczenie woli wyznaniowej osoby prawnej [“Acting on behalf of denominational legal entity”], Kraków: Księgarnia Akademicka, 2019, 774 pp. The book is an in-depth study in civil law which will likely be of huge importance for legal practice in Poland; it also contains, however, important contributions of historical and comparative nature, which allow to put the main issue discussed in it in a very broad context.

Secondly, the achievements of two other collaborators of the Department of Ecclesiastical and Denominational Law - most of which were concerned with legal historical issues - culminated in their receiving academic degrees. The first was Dr. Katarzyna Krzysztofek, who was awarded the degree of habilitated doctor (pursuant to the resolution of the Council of the Faculty of Law and Administration of the Jagiellonian University from May 27, 2019). The second scholar from the Department who was awarded a degree was Dr. Michał Ożóg, who defended his doctoral thesis titled Gwarancje wolności sumienia $i$ wyznania w podmiotach leczniczych w Polsce [Guarantees for Freedom of Conscience and Religion in Medical Units in Poland] on $16^{\text {th }}$ September 2019. Having received his doctoral degree, Dr. Ożóg was employed by the Chair in October 2019.

Dr. Hab. Krzysztofek, Dr. Strzała, and Dr. Ożóg were also busy in 2019 working on their respective chapters of a monograph, that they are preparing within the framework of the central research project of the IPN (National Memory Institute), concerning the attitude of the communist authorities towards Churches and Denominations in Poland in the years 1944-1989. Dr. Hab. Mikuła and Dr. Ożóg were also collaborating with the team of Prof. Bartosz Brożek in their project titled "Humanistyka w Dialogu" [„Humanities in Dialogue”], and Dr. Hab. Mikuła was engaged in preparation of the research units working on legal-historical issues for cooperation with the structures related to the IDUB initiative (cf. above).

\section{Chair of the History of Administration and Administrative Ideas}

In 2019, although the Chair of History of Administration and Administrative Ideas did not organize any conferences on its own, the professors of that unit were engaged in undertakings involving other chairs of the Faculty. I.a. Prof. Dorota Malec chaired the jubilee part of the conference devoted to source editions in September (see above). 
Professor Malec also took part in other undertakings: i.a., she presented her contribution to the discussions and disputes on the legal conditions and the constitution of the $2^{\text {nd }}$ Republic of Poland in the Legislative Sejm (1919-1922) during a conference held at the Polish Academy of Arts and Sciences (PAU) in Cracow in commemoration of the centennial anniversary of the convocation of this parliamentary institution („W stulecie Sejmu Ustawodawczego RP 1919-1922", October 9 $\left.{ }^{\text {th }}, 2019\right)$.

Dr. Hab. Paweł Cichoń continued his studies on the constitution, internal policy, and administration of the Free City of Cracow (1815-1846), as well as collective bodies and single-person authorities in Polish local government and the influence of the state organs on the functioning of the Bar on Polish territory in the $19^{\text {th }}$ century. He presented the results of his research at various conferences, i.a. the "Freedom, Religion and Sovereignty. Modern Phenomena and Future Challenges" conference in Warsaw in September, and the "Banská Bystrica Days of Law in the Castle" in Banská Bystrica (Slovakia), in November 2019.

Dr. Marek Stus continued his research, i.a. on the history and contemporaneous issues of the notarial profession in Poland, and on aviation law. He took part in three international conferences: the "Linking generations for global justice" congress in June 2019, the "Bringing Justice Closer to European Citizens" conference in Gdańsk, October 2019, (where he presented a paper jointly with Dr. Paulina Święcicka), and the $7^{\text {th }}$ Conference on Aviation and Space Law and Technology in Rzeszów in April 2019); along with two other domestic conferences. He also presented a lecture for the law students of the Rzeszów University, being invited as a renowned specialist on aviation law.

As usual, the Chair was represented at the $8^{\text {th }}$ Symposium of the History of Bureaucracy in June 2019 in Sandomierz, where Dr. Hab. Paweł Cichoń, and Dr. Michał Nowakowski presented their papers.

\section{Chair of General Legal History}

In the year 2019, several professors of the Chair of General Legal History continued ongoing research projects, some of them being conducted in the framework of externally funded research grants. Among them were Prof. Andrzej Dziadzio's project, entitled „Prawo własności w orzecznictwie sądów Wolnego Miasta Krakowa: Z dziejów stosowania Kodeksu Napoleona (Code civil)" [Property Law in the judicature of the Courts of the Free City of Cracow: From the History of Application of the Napoleonic Code Civil], in which Dr. Piotr Michalik and Dr. Mateusz Mataniak were also engaged, and the "Volumina Constitutionum" project, which was supported by the Ministry of Research and Higher Education through the National Programme for the Development of Humanities [NPRH]. Dr. Hab. Marcin Kwiecień was the Chief Investigator for this latter project in which Prof. Stanisław Grodziski and Dr. Krzysztof Fokt also took part. The scholars of the Chair also continued their ongoing research outside of official research funding formats. I.a. Dr. Jan Halberda continued his work on the institution of the estoppel in Anglo-American private law (his book on that topic is going to be published in 2020). 
Some results of research conducted by the professors of the Chair were presented at both domestic and international conferences. I.a., two of them took part in the "Central and Eastern European Legal History Conference" in Vienna, $25^{\text {th }}-27^{\text {th }}$ September, 2019, where Prof. Dziadzio spoke on the Code Civil in the jurisdiction of the courts of the Free City of Cracow as a case of hybrid legal practice on the boundary of the French and Austrian legal cultures (,Der Code civil in der gerichtlichen Rechtsprechung in der Freien Stadt Krakau, 1815-1846. Zwischen französischer und österreichischer Rechtskultur"), and Dr. Piotr Michalik commented on some cases from the history of the application of the Napoleonic Code Civil, concerning the institution of ownership in judicial decisions in the Free City of Cracow (1815-1846). Prof. Marian Małecki took part in the "Fifth International Mount Ararat and Noah's Ark Symposium", hosted by Ağrı İbrahim Çeçen University in Turkey on $16^{\text {th }}-18^{\text {th }}$ October 2019 , and in a conference in Poznan in June, 2019 commemorating the Treaty of Versailles, where he spoke on the Silesian Uprisings (1919-1921) and the plebiscite in Upper Silesia (1921).

Prof. Małecki also published two monographs: Spod ostrza gilotyny. Proces karny o szpiegostwo w III Rzeszy w świetle akt Gertrudy Świerczek i grupy „,U-2” Armii Krajowej ["From under the blade of a guillotine: Penal process for espionage in the III Reich in light of the procedural files concerning Gertruda Świerczek and the «U-2» Group of the home Army"], Zabrze - Tarnowskie Góry 2019, pp. 335, and PszczynaTychy 1919. I powstanie ślaskie na ziemi pszczyńskiej ["Pszczyna-Tychy 1919. The First Silesian Uprising in the lands of Pszczyna"], Zabrze - Tarnowskie Góry 2019, pp. 96. He also edited a book devoted to Professor Grodziski: Z profesorem Stanisławem Grodziskim przez wieki dziejów prawa, ustroju, wojskowości i historii lokalnej ["With Professor Grodziski through the centuries of the history of law, constitution, military and area studies"], Pszczyna 2019, pp. 26. Beyond this, he published a few minor texts, and co-organized various undertakings related to the $100^{\text {th }}$ anniversary of the First Silesian Uprising and the Polish-Czech conflict in the Cieszyn Dukedom, as well as the $80^{\text {th }}$ anniversary of the outbreak of the $2^{\text {nd }}$ World War, including occasional press releases, postcards, TV programs, expositions, and the unveiling of a plaque commemorating the soldiers of the Upper Silesian Home Army's Intelligence unit (the "Stragan" group).

\section{Chair of the History of Political and Legal Doctrines}

In the year 2019 the professors of the Chair continued their research and presented its results during various meetings and in more than a dozen publications. Among these there was one book (A. Ceglarska, Polityka i Sprawiedliwość w Grecji przedsokratejskiej [Politics and justice in pre-socratic Greece], Warszawa: Wolters Kluwer, 2019, 309 pp.) and two articles in English (I. Barwicka-Tylek, The Polish-Lithuanian Commonwealth as a Border Experience of the City, "Acta Universitatis Sapientiae, European and Regional Studies", 2019, vol. 15, pp. 15-30; A. Ceglarska, (R) evolution - the concept of political transformations in ancient Greece, „Studia Interkulturowe Europy ŚrodkowoWschodniej", 2019, t. 12, pp. 3-17). Especially worth noting are the book by Dr. Anna Ceglarska, being the first publication in Polish presenting the political notions of 
presocratic Greece, and the four chapters in a monograph concerning medical law (System Prawa Medycznego. Tom II. Czesść 2. Regulacja prawna czynności medycznych, tech. eds.: M. Boratyńska and P. Konieczniak, Wolters Kluwer Polska, Warszawa 2019), written by Dr. Jacek Malczewski (who also became a member of the editorial board of the journal "Przegląd Prawa Medycznego" [Review of Medical Law], affiliated with the Warsaw Medical University).

In September 2019 Dr. Hab. Iwona Barwicka-Tylek, Dr. Jacek Malczewski, and Dr. Anna Ceglarska presented their papers during the Convention of the Chairs of the History of Political and Legal Doctrines in Lublin, and Dr. Hab. Iwona Barwicka-Tylek, and Dr. Anna Ceglarska took part in the $14^{\text {th }}$ CEENJ Conference "Jurisprudence in Central and Eastern Europe" organized by the Central and Eastern European Network of Jurisprudence in Bratislava, speaking on contemporary legal debate in Poland and Europe. Dr. Hab. Iwona Barwicka-Tylek also took part in a conference concerning contemporary tendencies in the labour market in Płock in May, 2019 (where she coordinated an international session and presented a paper herself), and in the Liberty Fund Colloquium in Sestri Levante (Italy), in October/November 2019, devoted to the thought and legacy of Vilfredo Pareto.

Dr. Hab. Iwona Barwicka-Tylek took part in the programme of the Ministry of Research and Higher Education of Poland titled „Masters of Didactics” co-funded by the European Social Fund, in which she learned teaching and tutoring methods through a working visit in Ghent and prepared a new course herself, which has been made available for students beginning in the winter semester 2019/20. Dr. Agnieszka Adamczak continued her research and cooperation with the Keimyung University in Daegu (South Korea), and in April and May 2019 she worked as a visiting scholar in the University of Buffalo (SUNY), studying the importance of imagination in the political thought of Henry David Thoreau.

The Chair also collaborated actively with the Student Learned Society of Political and Legal Doctrines, which organized two conferences and published a monograph (Mit polityczny, eds. A. Czarnecka, P. Eckhardt, K. Zyzik, Wydawnictwo Kasper, Kraków 2019, with foreword by Dr. Agnieszka Adamczak).

It is also worth mentioning here that on $4^{\text {th }}$ March, 2019, Katarzyna Du Vall defended summa cum laude her doctoral thesis written under the supervision of Prof. Krystyna Chojnicka, entitled „Prawo polskie wobec totalitaryzmów w regulacjach Konstytucji RP i Kodeksu Karnego" ["Polish Law in relation to totalitarianisms in the regulations of the Constitution of the Republic of Poland and the Penal Code].

\section{Chair of Roman Law}

In 2019, the proceedings of the $3^{\text {rd }}$ Sino-Polish Seminar on Comparative Law were published (Theory and Practice of Codification: the Chinese and Polish Perspectives, eds. Chen Su, F. Longchamps de Bérier, P. Grzebyk, Beijing 2019) by the Chinese Academy of Social Sciences in Beijing (CASS). Also in 2019 a collective volume concerning the phenomenon of decodification of law, edited by Prof. Franciszek Longchamps De Bérier, 
was published, containing, i.a., contributions from himself, Dr. Karolina Wyrwińska, Dr. Paulina Święcicka, Dr. Grzegorz Blicharz, Piotr Łochowski, and Kamil Stolarski. Dr. Grzegorz Blicharz edited or co-edited ten books (five in Polish, five in English) within the framework of the "Public Order Protection" project, which covered five different topics: Freedom of Speech, Freedom of Conscience, Freedom of Religion, Public Policy and Public Morality Clauses, and Protection of Marriage, Children and Family. For the sake of publishing high-quality collective works, the editors gathered almost 40 experts from around the world: Australia, South America, North America, and Europe, and ten high profile reviewers from Poland and United States (the books may be ordered at the Institute of Justice Press, http://wydawnictwo.iws.gov.pl).

Prof. Franciszek Longchamps De Bérier represented the Chair in the $4^{\text {th }}$ Sino-Polish Seminar on Comparative Law, which took place on April 5" 2019 under the title "The Theory and Practice of Contract Law". The Head of the Chair also lectured during two commemorative events, devoted to Prof. Franciszek (IV) Longchamps De Bérier in June, 2019 in Wrocław, and Prof. Francesco Salerno in Salerno on May, 14 ${ }^{\text {th }}, 2019$. On $19^{\text {th }}-22^{\text {nd }}$ June, 2019, Prof. Franciszek Longchamps De Bérier and Dr. Grzegorz Blicharz took part in the $6^{\text {th }}$ "Workshop on the Ostrom Workshop" in the Indiana University in Bloomington, Indiana, having presented their papers in a special panel, the idea of which was proposed by Dr. Blicharz, titled "Governance and Law in Institutional Perspective. Historical Experience and the Future”. Representatives of the Chair: Prof. Franciszek Longchamps De Bérier, Dr. Grzegorz Blicharz, Kamil Sorka, and Piotr Łochowski also presented results of their research on the $73^{\text {rd }}$ World Congress of SIHDA (Société Internationale Fernand de Visscher pour l'Histoire des Droits de l'Antiquité), which was issued in September 2019 in the Old College of the University of Edinburgh. Dr. Hab. Łukasz Marzec, Dr. Paulina Święcicka, Dr. Karolina Wyrwińska, and Kamil Sorka also represented the Chair at a conference titled "Bringing Justice Closer to European Citizens" on $25^{\text {th }}-26^{\text {th }}$ October 2019 in Gdańsk, and presented their papers there. Prof. Franciszek Longchamps De Bérier, Dr. Grzegorz Blicharz, and Kamil Sorka also took part in the conference "Freedom, Religion and Sovereignty. Modern Phenomena and Future Challenges" in Warsaw in September 2019.

In 2019 the Chair organized three lectures by professors from abroad. Prof. David Forte, of the Cleveland-Marshal College of Law visited Poland as a professor of the Fulbright Distinguished Chair in the Warsaw University and presented a lecture titled "The Morality of Positive Law" (May, 19 ${ }^{\text {th }}$ ). Prof. Augusto Zimmermann, of the Sheridan College in Perth, Western Australia spoke on "Christian Foundations of the Common Law" (October, $2^{\text {nd }}$ ). And Prof. Iain Benson, of the University of Notre Dame in Sydney, Australia spoke on "Recent Challenges to Conscience and Religion in Canada, Australia, and South Africa" (October, $7^{\text {th }}$ ).

The Chair also continued its vivid cooperation with students, i.a. organizing the $10^{\text {th }}$ anniversary final of the student contest entitled "Roman Law and the Contemporary World" on June 3rd, 2019. 


\section{Laboratory of Source Editions}

In 2019, work on two major projects, aided by the Polish Ministry of Research and Higher Education through the NPRH program (National Programme for the Development of Humanities), was continued in the Laboratory: the "Fontes Iuris Lusatiae Superioris Vetustissimi" (headed by Dr. Krzysztof Fokt), and the "Volumina Constitutionum" (headed by Dr. Hab. Marcin Kwiecień). Apart from that, the IURA project (https://iura. uj.edu.pl) was continued under the supervision of Dr. Hab. Maciej Mikuła, with new features being introduced and new texts being prepared and published.

In March 2019, a new collaborator joined the Laboratory: Dr. Mateusz Mataniak, who has the important task of elaborating various $19^{\text {th }}$ century materials in order to publish them in the IURA Database. In this the first year of his employment, Dr. Mataniak also published his book in a prestigious series on Cracow: Rada Administracyjna Miasta Krakowa i jego Okregu (1846-1853) ["Administrative Council of the City of Cracow and its District, 1846-1853”], Kraków 2019 [Biblioteka Krakowska, nr 156].

On March $21^{\text {st }} 2019$, Dr. Mataniak spoke on the Galician Governorship, its organization and competences at the $19^{\text {th }}$ Century Seminar in the Jagiellonian University's Institute of History, and presented his paper during the $8^{\text {th }}$ Symposium of the History of Bureaucracy, in June 2019 in Sandomierz. On 19 th $^{\text {th }}$ December 2019 Dr. Krzysztof Fokt presented a lecture in the School for Historical Research (Schule für Historische Forschung) of the University of Bielefeld (Germany), entitled Ein Schöffenkollegium als Bewahrer und Stifter sozialen Friedens. Das Fallbeispiel Görlitz im 14. Jahrhundert [College of Benchmen as Creator and Warden of Social Peace: Case study of Görlitz in the $14^{\text {th }}$ century.].

Most of the information presented in the Chronicle was obtained through the kind collaboration of the Employees of particular Chairs and Departments, the information on the Chair of the History of Political and Legal Doctrines being collected by Dr. Anna Ceglarska. 